\title{
Challenging the rise of nationalist-religious parties in India and Turkey
}

\section{Nitish Dutt \& Eddie J. Girdner}

To cite this article: Nitish Dutt \& Eddie J. Girdner (2000) Challenging the rise of nationalistreligious parties in India and Turkey, Contemporary South Asia, 9:1, 7-24, DOI: 10.1080/713658720

To link to this article: http://dx.doi.org/10.1080/713658720

$$
\text { 冓Published online: } 01 \text { Jul } 2010 .
$$

Submit your article to this journal $₫$

Щ Article views: 80

Q View related articles $\sqsubset$

Citing articles: 1 View citing articles 지 
Contemporary South Asia (2000) 9(1), 7-24

\title{
Challenging the rise of nationalist-religious parties in India and Turkey
}

\author{
NITISH DUTT \& EDDIE J. GIRDNER
}

ABSTRACT Examinations of how the secular state deals with the threat posed by 'nationalistreligious' parties (as distinct from 'religious-nationalist' parties) has received little attention. Consequently, this paper focuses on the available strategies for dealing with relatively moderate nationalist-religious parties like the Refah Party in Turkey and the Bharatiya Janata Party in India. In particular, it examines two opposed approaches: that which seeks to exclude and isolate such parties, as in the case of Turkey; and that which adopts a policy of engagement, as in India. The paper then assesses the relative merits of these two strategies and concludes that the latter approach provides a more effective means of dealing with nationalist-religious parties, especially in democratic countries.

Of growing concern in recent times is the increasing prominence of religious 'fundamentalist' parties in the political arena in countries like India, Turkey, Egypt and Algeria. ${ }^{1}$ The electoral success of religious parties like the Bharatiya Jananta Party (BJP) in India and the Refah Party (RP) in Turkey, and their emergence as contenders for political power, are widely perceived to pose a threat to the secular state in the two countries. ${ }^{2}$ Although there is a growing literature focusing on the nature and sources of what is referred to as 'religious fundamentalist' political groupings, much less attention has been devoted to the strategies or means of dealing with the threat. This paper seeks to fill this gap in the literature by focusing on the cases of two dissimilar but secular democratic countries-India and Turkey — which face similar challenges to the secular state from nationalist-religiou s parties. Drawing their sustenance from Hinduism and Islam, the BJP in India and the RP in Turkey have succeeded, unlike more radical religious movements, in making their presence felt in the electoral arena through the ballot box. Significantly, the methods adopted by the state in the two countries to deal with the threat are diametrically opposite, and illustrate the

Correspondence: Nitish Dutt, Department of Political Science and Public Administration, Bilkent University, Bilkent 06533, Ankara, Turkey; e-mail:〈dutt@bilkent.edu.tr〉. Eddie Girdner, Department of Political Science, Bilgi University, Istanbul, Turkey; e-mail〈girdner@ibun.edu.tr 〉. 
problems and possibilities suggested by a policy of exclusion in Turkey and inclusion in India.

The choice of these two countries was dictated by the use of a 'most similar' systems design ${ }^{3}$ which involves holding constant all those variables that do not constitute the central concern of the study, thereby permitting the observation of variation in the dependent variable of interest to the analyst. In the context of this paper, the use of this design means selecting two parties which resemble each other as closely as possible with regard to contextual factors but differ significantly in terms of the phenomenon of interest. The cases of the Hindunationalist BJP in India and the Islamist-nationalis t RP in Turkey largely satisfy the requirements of the most-similar systems design in that the politics of religious resurgence in India and Turkey, especially in the electoral arena, paralled each other in many respects. At the same time, the state and most secular parties in India and Turkey have adopted a policy of inclusion and exclusion, respectively, to combat the perceived threat of religious nationalism to their secular systems.

From a cultural, social, economic and political perspective, Turkey and India are different in many respects with regard to their history, culture, political institutions, and religious persuasion among others. But they also share certain similarities which are central to the concerns of this paper. First, both Turkey and India are democracies and committed to the idea of a secular state which is enshrined in their respective constitutions. Second, both countries are confronted by nationalist-religiou s parties which managed to gain power through democratic means, thereby increasing the problem of dealing with them. Third, in recent years, the formation and disintegration of coalition governments in fairly rapid succession has been a characteristic feature of politics in the two countries. Fourth, the general ideological orientation, organization and strategy for gaining power by the RP and the BJP are quite similar in many respects.

These two parties, however, represent two different religious persuasions and this helps to increase the 'generalizability' of the findings to other countries. Based on a comparative analysis of the responses of two somewhat different political systems to the same type of threat, we draw some general inferences regarding the most advantageous means of dealing with nationalist-religious parties within a democratic framework. Finally, we examine the ability of such parties to govern, as well as the impact of wielding power on the political appeal of such parties. Before addressing these issues we briefly outline a number of similarities between the two parties regarding their electoral fortunes, ideology, organization and strategy for gaining power.

\section{Similarities between the BJP and RP}

The results of the May 1966 elections in India and the December 1995 election in Turkey marked a major watershed in the electoral history of the two countries. As a direct result of the elections, the two countries witnessed a seismic shift in the balance of power, with the secular parties suffering their worst-ever electoral 
defeat. Thus, for the first time in the history of the two countries, nationalistreligious parties emerged as winners in the electoral arena. Starting in the early 1990s, both the BJP and the RP became major contenders for political power with the BJP increasing its share of the vote eightfold between 1952 and 1999, while the RP managed to double its share between 1973 and 1995, followed by a drop in 1999 (see Figure 1). Their rapidly rising popularity meant that in a relatively short time, both moved from the fringes of the political spectrum to become the largest parties in their respective legislatures.

Part of the success of the two parties can be attributed to their efforts to provide those uprooted from their traditional environment with a bridging ideology; one, which while offering an intensely needed emotional tie with the past, also claimed to provide a philosophical and practical framework for coping with, and regulating change. ${ }^{4}$ The RP and the BJP, like religious revivalist movements elsewhere, are ambivalent in their principles reflecting contradictory tendencies and factions. Both parties adopt a moralistic tone and are adept at using some of the buzzwords of liberal politics like 'civil society', 'pluralism' and 'social consensus' even while denouncing and distancing themselves from the established 'system'. Both parties speak of a 'brotherhood' and a 'new social order' and advocate economic and ethnic nationalism, anti-communism and anti-westernism. ${ }^{5}$ However, after gaining power, both considerably toned down their anti-western rhetoric and in its post-1998 incarnation, the BJP with its new-found pragmatism seems to have opened out to the West. Both parties thrive on political opportunism and, like other parties, are prepared to compromise their principles in order to gain power. This fact is clearly demonstrated by the RP's 1996 efforts to form a coalition government, and the BJP's pre-1999 electoral urgency to form alliances with other regional parties regardless of the fact that none of them even remotely identified with its brand of religious nationalism.

The BJP and the RP are also similar in terms of their support base. Both parties appeal to those who feel uncomfortable with the secular elites in their countries, whom they consider to be artificial and alien. Not surprisingly, their traditional clientele consist of small businessmen, shopkeepers, small merchants, artisans and the more prosperous segments of the rural population. In India, the higher castes figure prominently in the BJP's support base. ${ }^{6}$ Over the years, both parties expanded their basis of support among the young and the urban population. By the 1990s, however, differences appeared in the support base of the two parties (see Tables 1 and 2). The RP, for example, tended to have greater appeal for women, while support for the Hindu-nationalist BJP differed little between men and women. Also, while the BJP received more support from the middle classes, the RP attracted larger numbers of the lower working class of unskilled workers who fill the shanty towns of the largest cities, particularly Istanbul and Ankara.

The pre and post-election maneuverings in the two countries also suggest some interesting parallels. In both countries, there was a lack of unity among secular parties. The respective first attempts of the BJP in 1996 and the RP in 


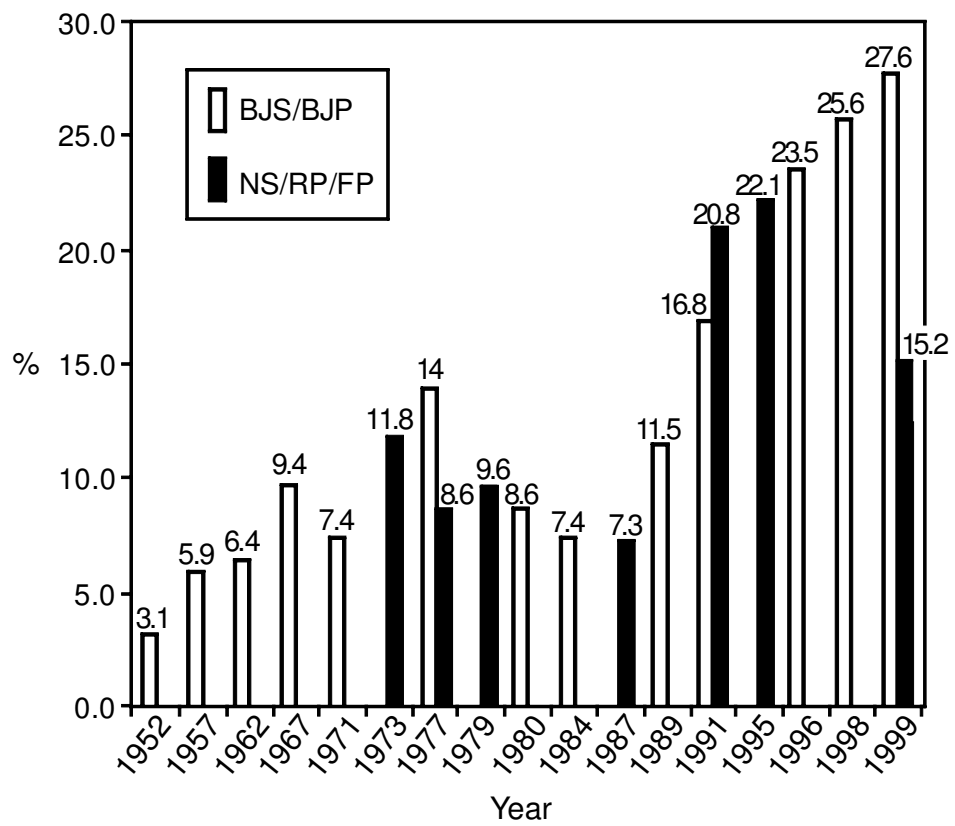

Source: J.C. Agarwal and N.K. Chaudhury, Elections in India 1998 (with comparative data since 1952), (New Delhi: Sipra Publications, 1998); Nermin Abadad-Unat, 'Legitimacy, Participation and Restricted Pluralism: the 1987 Elections in Turkey,' Ankara University Political Science Faculty Bulletin 44:1-2 (January-June 1988), pp. 17-38; and various issues of the Turkish Daily News, 1990-1996.

Figure 1. Electoral support at the national level for the NS/RP/FP and the BJS/BJP.

1995 to form a coalition government failed, faced with outright opposition from the secular parties. Ultimately, by forming coalitions with other parties, both succeeded in coming to power at the head of coalition governments. In each case, the two parties benefited both from disgruntled voters and a lack of unity among secular parties. In Turkey, the RP managed to form a government in alliance with the secular True Path Party (DYP). In India, the BJP, learning from its 1996 failure to gain power, changed tack. The BJP, at the cost of its 'holier than thou' posture, defeated the secular parties at their own game by forming a series of opportunistic electoral alliances with smaller regional parties. Together with these allies, the BJP emerged as the single largest vote-getter in the country. Helped by rifts between and within the secular parties, the BJP-led coalition was able to win the vote of confidence in Parliament and install, for the first time in India's history, an avowedly religious party at the helm of the national government. $^{7}$

The crucial difference for purposes of comparative analyses, however, centers around the exclusionist approach taken in Turkey and the inclusionist approach 
Table 1. Party support in Turkey by demographic and socio-economic status 1990 (\%)

\begin{tabular}{|c|c|c|c|c|c|c|c|}
\hline & $\begin{array}{r}\text { RP+ } \\
\text { Allies }\end{array}$ & ANAP & $\begin{array}{c}\text { DYP }+ \\
\text { DMP }\end{array}$ & DSP & SHP & $\begin{array}{l}\text { Non- } \\
\text { voters }\end{array}$ & Other \\
\hline \multicolumn{8}{|l|}{ Gender } \\
\hline Male & 4.8 & 31.2 & 14.8 & 8.5 & 21.4 & 10.5 & 8.9 \\
\hline Female & 7.7 & 15.9 & 17.4 & 17.6 & 20.0 & 12.9 & 8.4 \\
\hline$N=$ & $\begin{array}{c}(58) \\
\chi^{2}=49.6\end{array}$ & $\begin{array}{l}(217) \\
<\quad 0.001\end{array}$ & $(149)$ & $(121)$ & $(191)$ & $(108)$ & $(80)$ \\
\hline \multicolumn{8}{|l|}{ Age } \\
\hline $18-24$ & 9.0 & 23.8 & 14.8 & 8.5 & 21.2 & 12.7 & 10.1 \\
\hline $25-34$ & 7.1 & 19.5 & 15.0 & 14.6 & 20.2 & 13.9 & 9.7 \\
\hline $35-44$ & 3.3 & 27.0 & 15.6 & 16.6 & 19.9 & 10.4 & 7.1 \\
\hline $45-54$ & 6.8 & 24.1 & 18.8 & 14.3 & 21.8 & 9.0 & 5.3 \\
\hline $55-64$ & 2.5 & 22.2 & 22.2 & 9.9 & 22.2 & 8.6 & 12.4 \\
\hline $65+$ & 11.4 & 22.9 & 14.3 & 8.6 & 20.0 & 14.3 & 8.6 \\
\hline$N=$ & $\begin{array}{c}(58) \\
\chi^{2}=51 .\end{array}$ & $\begin{array}{l}(212) \\
<0.01\end{array}$ & $(149)$ & $(120)$ & $(190)$ & $(107)$ & $(80)$ \\
\hline \multicolumn{8}{|c|}{ Subjective Class } \\
\hline Upper & (3) & 17.5 & 11.9 & 14.3 & 27.8 & 19.8 & 6.3 \\
\hline Middle & 6.2 & 25.4 & 15.3 & 10.4 & 19.9 & 15.3 & 7.5 \\
\hline Skilled & 5.6 & 24.2 & 20.0 & 15.3 & 17.2 & 7.9 & 9.8 \\
\hline Unskilled & 8.2 & 23.9 & 16.0 & 12.3 & 22.2 & 6.2 & 11.1 \\
\hline$N=$ & $\begin{array}{c}(54) \\
\chi^{2}=61.2\end{array}$ & $\begin{aligned} & (210) \\
< & 0.001\end{aligned}$ & $(144)$ & (113) & $(187)$ & $(104)$ & (79) \\
\hline \multicolumn{8}{|l|}{ Income } \\
\hline Low & 4.3 & 23.8 & 17.5 & 12.2 & 23.8 & 8.3 & 10.2 \\
\hline Medium & 7.5 & 22.4 & 15.5 & 13.8 & 19.3 & 13.5 & 8.0 \\
\hline High & (1) & 42.9 & (3) & 9.5 & 19.0 & (3) & - \\
\hline$N=$ & $\begin{array}{c}(58) \\
\chi^{2}=31.9\end{array}$ & $\begin{array}{l}(212) \\
0.05\end{array}$ & (131) & $(119)$ & (189) & (107) & $(78)$ \\
\hline \multicolumn{8}{|l|}{ Education } \\
\hline None & 5.7 & 36.2 & 19.8 & 9.0 & 17.5 & 5.1 & 6.8 \\
\hline Primary & 6.1 & 23.7 & 17.4 & 15.9 & 18.4 & 9.0 & 9.4 \\
\hline Junior High & 6.3 & 18.9 & 11.6 & 13.7 & 23.2 & 15.8 & 10.5 \\
\hline Vocational & 13.3 & 8.9 & 13.3 & 11.1 & 17.8 & 26.7 & (4) \\
\hline \multicolumn{8}{|l|}{ College/ } \\
\hline University & (3) & 14.9 & 9.5 & 10.8 & 33.8 & 23.0 & (3) \\
\hline$N=$ & $\begin{array}{c}(54) \\
\chi^{2}=122.6\end{array}$ & $\begin{array}{l}(210) \\
<0.001\end{array}$ & $(142)$ & (118) & $(174)$ & $(96)$ & (74) \\
\hline
\end{tabular}

Source: World Values Study Group, World Values Survey 1990 (Ann Arbor: Institute for Social Research).

seen in India. In Turkey, the military presented a list of demands that the RP could not meet. Consequently, a case was initiated charging the party with violating the secular requirements of the constitution. The RP was declared illegal and its leader Necmettin Erbakan, was banned from politics for five years. ${ }^{8}$ In India, the BJP has enjoyed greater freedom to operate within the Indian political space, though at the state level it suffered some reverses in the form of having its government dismissed from office in Utter Pradesh. But, even after the destruction of the Babri Masjid in Ayodhya in 1992 and its violent 
Table 2. Party Support in India by Demographic and Socio-Economic Status 1990 (\%)

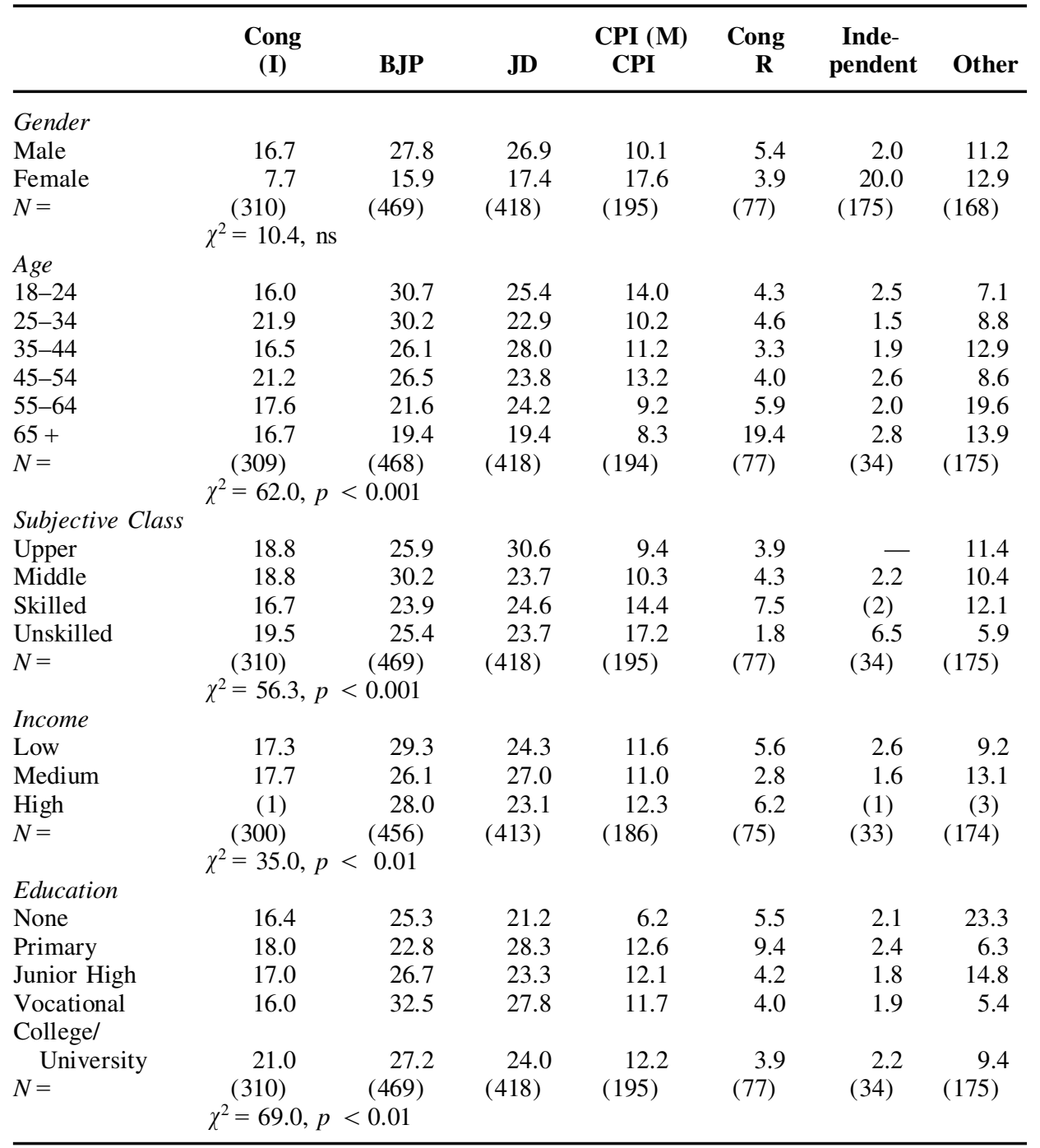

Source: World Values Study Group, World Values Survey 1990 (Ann Arbor: Institute for Social Research).

aftermath, the Vajpayee government continued to enjoy a fair amount of freedom in its efforts to govern.

The nationalist-religiou s RP was forced to compromise on its more extreme political postures, such as taking Turkey out of the European Customs Union and forming an 'Islamic Customs Union' with other countries from Pakistan to the Middle East. Similarly, after acquiring power, the BJP was forced to moderate its political platform in order to widen its public acceptance and support. This 
was evident with regard to the efforts of the BJP government to distance itself from its ideological allies, the Shiv Sena (SS) and the Vishwa Hindu Parishad (VHP), following the November 1998 assembly elections in three states. In the process, the party tended to alienate its existing basis of support.

In the final analysis, with regard to the threat posed by these parties to the secular state, what matters is their action rather than their rhetoric. Therefore, our argument does not imply support in any way to nationalist-religiou s parties. Quite the contrary, our argument is that once exposed to the political dynamics of rule, these parties will be subject to the contradictory pulls of holding on to their core supporters on the one hand, and making the compromises necessary to keep the coalition together and provide effective governance on the other. In other words, they must both moderate their agendas and perform successfully to maintain support. Under such circumstances it would be difficult to maintain their posture as a 'party with a difference'.

\section{The rise of the $R P$ and the $B J P$}

The RP and the BJP emerged, in part, as reactions to the perceived threats posed by the West to the traditional values and culture which form the basis of their respective societies. In Turkey, Islamic resurgence, repressed under Mustafa Kemal and Ismet Inonu from 1923 to the 1950s, started to gain strength under the Democrat Party (DP) government of Adnan Menderes. The first pro-Islamic Party to be organized in modern Turkey, the National Order Party (NOP) was founded by Necmettin Erbakan in 1969, later becoming the National Salvation Party (NSP), which participated in three governments in the 1970 s. ${ }^{9}$ By the 1970s, party cadres began to demonstrate hostility towards the ideas of Ataturk, enshrined in the state ideology of 'Kemalism'. As a result, the military regime closed down the party on the grounds that it was undermining the secular character of the state. In 1983, the party resurfaced as the Refah Party, under the prime ministership of the popular Turgut Ozal of the Democratic Socialist Party (DSP), who prided himself on being a devout Muslim. In the elections of 1984, the RP lost some support to Ozal, ending up with only $4 \%$ of the vote. Since the 1990s, however, the RP has recovered lost ground and continues to gain support, especially in the countryside, as well as among urban migrants who have swelled the shanty towns of major cities. Ignored by other parties, the RP has come to their rescue. Today, the party (reorganised as the Fazilet or Virtue Party), like the BJP in India, is modern in its techniques, better organized than the other parties, and focuses its social, political and economic activities at the grassroots level to mobilize its supporters. Its appeal is based on its opposition to big capitalism and communism, the strengthening of national and moral values, emphasis on heavy industry, independence from the West, and stronger ties with the Islamic world. ${ }^{10}$

A number of factors have contributed to the rise of the RP. Among them were Ozal's support for greater religious freedom, the enormous growth in Islamic schools, the success of Islamic businesse $\mathrm{s}^{11}$ and, last but not least, the help of the 
Turkish military. Ironically, while demanding the closure of the religious schools today, it was the military which mandated religious education as a compulsory component of education in primary and secondary schools and gymnasiums, even making this requirement a part of the Constitution. ${ }^{12}$

Tracing its political ancestry to the Hindu Mahasabha (Great Assembly), formed at the turn of the century, the BJP, in terms of its ideology, organization and leadership structure, is the direct descendant of the Bharatiya Jan Sangh (BJS).$^{13}$ Following the electoral reverses of the BJS as part of the Janata Party (JP) in 1980, it broke away from the JP and renamed itself the Bharatiya Janata Party in order to emphasize its continued links to the Janata Party's populist orientation. In its effort to broaden its appeal, the new party under the leadership of its founding president, Atal Behari Vajpayee, made a conscious effort to divest itself of the chauvinistic Hindu nationalism of the Jan Sangh. Like the RP the party committed itself to nationalism, national integration, democracy, positive secularism and value-based politics. ${ }^{14}$ The leaders of the new party, like their Turkish counterpart rejected both capitalism and Marxism, arguing that while the former created inequality in society, the latter denied individual freedom. ${ }^{15}$

\section{The 1995 elections in Turkey and the 1996 elections in India}

The socio-economic environment and the national mood in Turkey and India immediately preceding the 1995 and 1996 elections, respectively, defined the cutting-edge issues underlying the campaigns. Economic concerns, like rising prices, remained paramount in both countries, especially in Turkey, given its runaway inflation. Cynicism remained pervasive among the general population as reflected by their attitude toward political leaders and the governmental process in general. A survey of citizen attitudes in the two countries in the early 1990 s revealed that a majority of people, around 55\% in India and $78 \%$ in Turkey, felt that the country was run for the 'benefit of a few big interests', while about $42 \%$ in India and $31 \%$ in Turkey believed they could trust their government to do right 'always' or 'most of the time'. ${ }^{16}$ As in India, corruption was also a major issue in the Turkish elections. In India, a series of financial scandals, starting with the Hawala scandal involving former Prime Minister P. V. Narasimha Rao resulted in widespread opposition charges of corruption against him and his government. ${ }^{17}$ In like manner, Prime Minister Ciller in Turkey was confronted with accusations of corruption related to her personal wealth and her use of a 'slush' fund. Not surprisingly, corruption ranked high among the concern of citizens in both countries just prior to the elections. ${ }^{18}$

When the results of the Turkish elections became clear (see Table 3), the formation of a secular government which excluded the Islamists appeared problematical. At the national level the RP, with $22.1 \%$, received the largest share of the vote, followed by $20.3 \%$ for the Motherland Party (ANAP), $19.8 \%$ for the True Path Party (DYP), 15.2\% for the Democratic Left Party (DSP), and $11.2 \%$ for the Republican People's Party (CHP). The ultra-nationalist National Action Party (MHP) failed to garner the minimum $10 \%$ and thus failed to secure 
Table 3. Results of the 1995 Elections in Turkey and the 1996 Elections in India

\begin{tabular}{llllllr}
\hline & Turkey & & & \multicolumn{3}{c}{ India } \\
\cline { 1 - 3 } \cline { 5 - 6 } Parties & Votes & Seats & & Parties & Votes & Seats \\
\hline RP & 22.1 & 157 & & BJP & 20.3 & 161 \\
ANAP & 20.3 & 132 & & INC & 28.8 & 140 \\
DYP & 19.8 & 136 & & JD & 8.1 & 47 \\
DSP & 15.2 & 75 & & CPI (M) & 6.1 & 32 \\
CHP & 11.2 & 50 & & CPI & 2.0 & 12 \\
MHP & 8.2 & - & & INC (Tiwari) & 1.5 & 4 \\
Others & 4.2 & - & & Others & 33.1 & 147 \\
Total & 100.0 & 550 & & Total & 99.9 & 543 \\
\hline
\end{tabular}

Source: J. C. Aggarwal and N. K. Choudhary, Elections in India 1998 with comparative data since 1952 (New Delhi: Sipra, 1998); and Hurriyet, 25 December 1995, p 19.

representation in the national assembly. In terms of parliamentary seats, the RP bagged the largest number with 158 of the 550 seats. The DYP, with 135 seats, came in second, followed by the ANAP with 133, the DSP with 75 and 40 for the CHP. ${ }^{19}$ However, no party succeeded in gaining the 276 seats needed to rule. In this situation, a logical solution would have been for the center-right DYP and the center-left ANAP to form a coalition, both being secular parties. But the leaders of the two parties, Ciller and Yilmaz, respectively, seemed determined to keep the other out of power while at the same time refusing to enter into an alliance with Refah. In addition, the DSP declared it would support a CenterRight coalition, but only from the outside.

In India, the Hindu BJP, like the Islamist RP in Turkey, emerged as the biggest gainer with the Congress as the worst loser (see Table 3). Going into the elections, the BJP held 128 seats and $20 \%$ of the vote compared to the Congress(I)'s 274 seats and 36.5\%. When the May 1966 election results were announced, the BJP emerged as the winner with 163 seats and $25.5 \%$ of the vote while the Congress secured 136 seats and $28.1 \%$ of the vote. ${ }^{20}$ Hence, even though the BJP received less votes than the Congress (I), it polled a larger share of the seats because of its more concentrated bases of support. India was faced with a difficult situation; as no party enjoyed a majority the result was a hung Parliament.

\section{Post-election coalition politics in Turkey and India}

The political maneuverings that followed the elections in the two countries were almost mirror reflections of each other. An exclusionist strategy formed the centerpiece of the secular parties and the axiom of 'my enemy's enemy is my friend' formed the basic rationale behind alliance politics. The December 1995 Turkish national election, like the May 1996 one in India, was contested by a number of parties within a fragmented political system. In Turkey, the center- 
right DYP and ANAP were the major contenders, having held power since the military relinquished it in 1982. The major challengers were two center-left parties, the DSP and the CHP. Increasingly, these centrist parties had been challenged by the Islamist RP. Also contesting the elections were the ultranationalist National Action Party (MHP) of former military leader Alparslan Turkes and the Grand Unity Party (BBP) which entered into electoral alliance with the ANAP. In India, the main contenders were the centrist Congress Party, the right-wing BJP, the left-wing Communist parties (primarily the CPI and CPM), the left-of-center Janata Party and other smaller regional parties.

The Welfarepath/Erbakan-Ciller coalition was driven both by Ciller's desire to avoid further parliamentary inquiry into her previous affairs and her blind political ambition. RP leader Erbakan announced the landmark coalition government with the DYP in late June 1996. Even though Erbakan took care to moderate the RP's radical image ${ }^{21}$ the RP ran into trouble with the military and the secular elites over the issue of the closure of the imam hatip religious schools which were regarded as vehicles for undermining the secular state. The RP refused to budge on the issue. The Constitutional Court, under pressure from the military, declared the RP illegal and banned its leader Erbakan from politics for five years. ${ }^{22}$ As a result, the party changed its name to the Fazilet (Virtue) Party, sought to refurbish its image as distinct from Refah, and continues to operate within the political system. The exposure of the RP to power and its misuse of the same to further its religious agenda resulted in the party ending up third in the April 1999 local and national elections in Turkey. It was beaten at the polls by both the DSP and the NAP. In addition, the nationalist upsurge created by the capture of Kurdish Worker's Party leader Abdullah Ocalan in Kenya in February 1999 helped to boost support for the DSP and the NAP and take votes away from the Virtue Party.

Following the 1996 election, politics in India resembled in many ways developments in Turkey. The Congress(I) Party was humiliated at the polls, and Prime Minister Rao was forced to submit his resignation. With a hung Parliament, regional bosses assumed great importance and descended on Delhi to jockey for power. The BJP and its allies, as the largest grouping, formally staked its claim to put together a parliamentary majority. Its leader, Vajpayee, was invited by President Shankar Dayal Sharma to make the first attempt to form a government. This proved to be a Herculean task since the other parties banded together in an effort to defeat the BJP through a vote of no-confidence, while engaging in frantic bargaining to form an alternative government capable of commanding a majority.

The problems facing the BJP became immediately apparent on 16 May 1996. Ten Bahujan Samaj Party (BSP) deputies, representing India's lowest castes and expected to back the BJP, had second thoughts about joining a coalition led by the predominantly upper-caste, Hindu-nationalist BJP, leaving the party only with the support of two small parties; the Shiromani Akali Dal and the Harayana Vikas Party. Realizing that it would be virtually impossible for him to create a majority government and wanting to avoid the embarrassment of losing the vote, 
Vajpayee submitted his resignation to the president after the shortest tenure as prime minister in India's history. His resignation cleared the way for the National Front/Left Front (NF/LF) coalition to form a United Front government under the leadership of H.D. Deve Gowda. The new coalition, with the support of the Congress(I) and the left parties from the outside, was able to win a vote of confidence and form a government. However, like the last experiment with a coalition government, this new one also proved short-lived. The withdrawal of support by Congress on 11 April 1997 led to the downfall of the 10 month-old Gowda coalition government. It was followed by another United Front government led by I.K. Gujral, with the help of the Congress(I) from the outside. However, this government followed in the footsteps of its predecessor, succumbing to its own internal contradictions. ${ }^{23}$ The elections that followed in 1998 witnessed the formation of the second Nationalist-Hindu dominated coalition government led by Atal Behari Vajpayee as Prime Minister. Along with its allies, it emerged as the largest political grouping in the country and further enhanced its electoral standing.

To a significant degree, the electoral successes of the BJP and the RP were partly a function of their ability to project themselves as more cohesive, better organized, less corrupt and better able to deal with the economic problems facing their respective countries than their rivals. Both parties were led by nationally popular leaders; Vaypayee in India and Erbakan in Turkey. Their success was also facilitated by the inability of secular parties to provide an effective and 'clean' government at the center.

\section{Inclusion or exclusion?}

The continuation of the RP in its new reincarnation as the Virtue Party (Erbakan, despite being banned from politics, continues to exercise ultimate power) suggests that it is very difficult to prevent nationalist-religious parties from operating within a democratic framework through a policy of exclusion. First, by declaring the RP illegal and banning its leader Erbakan for five years, from politics, the Constitutional Court, presumably under pressure from the military, may have succeeded in conveying the false impression that the problem associated with a religious party has been resolved. In fact, it might have succeeded only in compounding it. For instance, it might have helped to create a 'martyred' image for the now defunct RP which the newly formed Virtue Party (VP) could exploit in the next election if the present government led by prime minister Bulent Ecivit fails to deliver. Even more problematic is the prospect that religious radicals within the RP might be driven underground.

Second, from the perspective of the ballot box, an exclusionist strategy has clearly proved to be counterproductive. Both parties made spectacular electoral gains in the 1990s and the BJP in India continues to go from strength to strength. After the September/October 1999 elections, it has now become a national party. Hence, the BJP has been able to thrive at the expense of the secular parties, plagued by scandals and incessant inter-party squabbling. The decision of the 
Congress(I) to withdraw its support from the Gowda government lend credence to Vajpayee's pre-election claim that the 'stability issue' was no longer a Congress(I) monopoly. ${ }^{24}$ In the process Congress(I) has been the biggest loser with its representation in parliament having dropped to an all-time low. Having failed to provide a viable alternative after keeping the BJP out of power, the secular parties led by the Congress(I) provided the BJP with a powerful argument to win favor with the electorate in the 1999 elections, when it emerged as the largest party. The Kargil War and India's victory under Vajpayee's leadership provided an additional bonus.

Third, in a democratic polity, what makes a policy of exclusion less defensible is the fact that these parties came to power through democratic means and in the process emerged as the largest parties in the country. Under these circumstances, preventing them from exercising power ignores the wishes of a large segment of the electorate of these countries. For instance, as public opinion polls in India suggest, a significant segment of the electorate that includes 'scuppies' (saffronclad yuppies) does not obviously share the fears of the elites and intelligentisi a with regard to the threat posed by a nationalist-Hind u government in India. ${ }^{25}$ In addition, a majority of the people preferred a BJP led government with Vajpayee as its leader. Illustratively, the results of a Times of India poll conducted on 14 August 1999 shows that $44 \%$ of the public favored a BJP government and 57\% considered Vajpayee to be the best leader. ${ }^{26}$ Given the political maturity of the Indian electorate, which it has demonstrated quite frequently, it would be more advisable to rely on astute voters to politically bury the BJP if it threatens India's secular polity.

Finally, a policy of isolating or marginalizing moderate nationalist-religiou s parties only helps play into the hands of the religious extremists and transform their political moderation into political extremism, especially in the absence of any institutional avenues for getting their preferences represented. The situation in Algeria and Egypt comes to mind where efforts to exclude the Islamic parties by force has resulted in the politics of violence and terrorism. In Algeria the military-backed government of President Liamine Zeroual canceled the 1992 elections which the Islamic Salvation Front was expected to win. The result was widespread violence which has so far claimed the lives of over 75,00 Algerians. In Egypt, the banned Muslim Brotherhood poses similar problems for the Egyptian government with terrorists attacks posing a real problem.

In contrast, an inclusionist policy offers a number of advantages in dealing with nationalist-religious parties. In this connection the Turkish and Indian experience with the RP and BJP is instructive. The inability of the RP-led coalition to survive for more than 10 months, even after dramatically altering its religious face, is suggestive of some of the pitfalls confronting nationalistreligious parties in their quest to undermine the secular state. The initial policy of inclusion adopted by the Turkish state helped to expose the RP to the risks faced by a non-secular party governing a secular state, which were to prove instrumental in its downfall. As in the case of the BJP in India, the RP did not demonstrate that it was more adept at running the economy. It tended to alienate 
women and secular elites, crossed paths with big business houses in its hostile policy toward Europe, bungled foreign policy initiatives in Libya and other Islamic countries, continued security co-operation with the USA, and repeatedly appeared to be climbing down from its promises to be 'different'. Its staffing of key bureaucracies with large numbers of Islamists caused widespread concern even before the military took action. All of this helped to undermine its credibility and public standing. Similarly, the BJP has been seen back-tracking on its position on key issues like the building of the temple at the Babri Mosque site, introducing a uniform civil code, and repealing Article 370 of the constitution (pertaining to Kashmir's special status).

The policy of inclusion meant that nationalist-religion s parties were no longer able to to sit in the opposition and criticize the government for political profit. They were now in the 'hot seat' themselves and subjected to the same king of oppositional scrutiny and criticism. Having had a chance to run the country and having turned in a poor performance, it was more difficult to project themselves as somehow better able to govern the country compared to secular parties. The less than satisfactory performance on the political and economic fronts by the RP and the BJP are cases in point. The RP which came to power on tall promises of improving the lives of the ordinary Turks, failed to give any indication that it was capable of doing so. It became enmeshed in a major controversy regarding implementing education reform, and involved the closure of religious schools demanded by the military. The party's efforts to remove women employees from office, and pack pivotal bureaucracies with religious school graduates also contributed to its demise. ${ }^{27}$ In India, Vajpayee's coalition government, like its predecessor has been staggering from one crisis to another with its partners pulling in different directions. For this reason, according to many members of the Sangh Parivar and BJP, the previous BJP-led government was not able to measure up to their expectations. ${ }^{28}$ Such comments from its own ranks cannot help but undermine the faith of its supporters. On the political front, its Pokhran ploy (testing fire nuclear devices in May 1998), seems to have left the BJP without any concrete political gains at the electoral hustings. ${ }^{29}$

In the absence of effective rule by the secular parties, a policy of exclusion also helps parties like the RP and BJP to attract disgruntled voters and create sympathy. Partly for this reason, both the parties were able to attract a large protest vote from people who perceived the secular parties as being deeply mired in corruption or incapable of providing effective government. Having never been in power meant they were able to get the benefit of the doubt from the electorate. From this perspective, the significant increase in support for the RP in the 1995 elections has to be regarded as a vote against the secular parties, rather than a vote for the RP. Similarly, the gains made by the BJP in the 1998 and 1999 elections reflect a protest vote against the perceived inept, corrupt secular parties and a vote for Vajpayee, rather than a vote for the BJP's ideology of Hinduvta. In short, while a policy of exclusion and isolation was meant to combat the threat posed by religious parties like the RP and the BJP, in effect it ended up 
by helping them to expand their support within the electorate and ultimately come to power.

In addition, there seems to be some discrepancy, both in India and Turkey, between elite and popular attitudes toward these nationalist-religiou s parties ( see Table 4). Most of the supporters of the BJP seem to relate more closely to the nationalistic stance of these parties, even though they may not care for their religious rhetoric. Partly because of this reason, the religious profile of BJP supporters is not very different from the rest of the population. For instance, on a number of indicators of religious orientation, BJP supporters are quite comparable to the general population. Contrary to popular elite perceptions in India, a smaller proportion of BJP supporters consider themselves to be religious than the general population, and pray about as often as the rest. More importantly, in terms of religious identity, prospective BJP voters were less likely than the rest of the population to identify themselves as 'above all a Hindu', and more inclined to think of themselves as 'Indians first and members of a religious group second'. Even more surprising is the finding that BJP partisans were less likely than their Congress counterparts to declare themselves as being 'religious', nor did they consider religion to be any more important than the Congress(I) supporters. In short, there is no convincing evidence to suggest that a majority of BJP supporters are 'Hindu fanatics' or even religious. ${ }^{30}$ They do not appear to from a base from which the BJP can draw the requisite strength to dismantle the secular state. Although, in the case of Refah supporters there are some differences on three of the five indicators for Turkey, these differences are considerable only with regard to the extent to which they attend religious services. Consequently, increasing support for moderate religious parties should not be interpreted as representing identification with the religious goals of these parties, but probably their nationalistic message.

Like the RP the BJP faces an array of parties united only by their common determination of keeping India a secular state. Given the inability of the two nationalist-religiou s parties to obtain a majority in the 1995 and 1999 elections in Turkey, and the 1996 and 1998 elections in India, they were forced to enter into opportunistic, electoral understandings with other parties. As a result, they had to compromise on their extremist platforms and alienate their more extreme supporters. For example, in their desire to taste power, the leaders of the two parties were more than willing to make major concessions to moderate their respective parties' political programs. In Turkey, Erbakan had to back down from his vow to 'change the system', take Turkey out of the European Customs Union and transform it into an Islamic state. He was forced to accept the secular basis of the Turkish state. ${ }^{31}$

Similarly, the BJP has been forced to make compromises in order to win allies and gain power at the risk of alienating its more extreme supporters. It is evident from the repeated statements of BJP leaders like Vajpayee and L.K. Advani that the party has put on the back-burner the three corner stones of its 50 year-old ideology: building a temple at the Babri Mosque site, introducing a uniform civil code, and repealing article 370 of the constitution that gives special status to the 
Table 4. Religiosity in India and Turkey (\%)

\begin{tabular}{|c|c|c|c|c|}
\hline & India & BJP & Turkey & $\mathbf{R P}$ \\
\hline Importance of religion $^{a}$ & $(1.8)$ & $(1.5)$ & $(1.6)$ & $(1.2)$ \\
\hline Very & 49.3 & 59.2 & 61.2 & 79.1 \\
\hline Quite & 32.1 & 33.9 & 23.0 & 18.3 \\
\hline Not very & 12.0 & 4.4 & 10.6 & 2.3 \\
\hline Not at all & 6.6 & 2.5 & 5.2 & 0.3 \\
\hline$N=$ & 2495 & 460 & 1018 & 43 \\
\hline \multicolumn{5}{|l|}{ Is religious: ${ }^{b}$} \\
\hline Yes & 83.7 & 84.4 & 74.6 & 88.1 \\
\hline No & 15.7 & 14.7 & 24.3 & 11.9 \\
\hline Atheist & 0.6 & 0.9 & 1.2 & - \\
\hline$N=$ & 2441 & 462 & 1002 & - \\
\hline \multicolumn{5}{|l|}{ Sense of religious identity: ${ }^{c}$} \\
\hline Above all a Hindu & 42.9 & 29.2 & - & - \\
\hline Above all a Muslim & 5.5 & (4) & - & - \\
\hline $\begin{array}{l}\text { Above all member of another } \\
\text { religious denomination }\end{array}$ & 3.3 & (5) & - & - \\
\hline $\begin{array}{l}\text { Indian first and member of } \\
\text { religious group second }\end{array}$ & 48.3 & 68.9 & - & - \\
\hline$N=$ & 2511 & 469 & - & - \\
\hline Attend religious services: ${ }^{d}$ & $(2.4)$ & $(2.5)$ & $(3.5)$ & $(2.4)$ \\
\hline More than once a week & 30.9 & 30.1 & 14.0 & 41.9 \\
\hline Once a week & 28.3 & 23.7 & 20.7 & 18.6 \\
\hline Once a month & 16.6 & 43.5 & 3.4 & 4.7 \\
\hline $\begin{array}{l}\text { On religious festivals } \\
\text { and Holidays }\end{array}$ & 12.1 & 2.8 & 31.0 & 31.0 \\
\hline$N=$ & 2511 & 469 & 1017 & 43 \\
\hline How often pray: ${ }^{e}$ & $(1.7)$ & $(1.9)$ & - & - \\
\hline Often & 42.1 & 40.3 & - & - \\
\hline At times & 46.1 & 46.1 & - & 一 \\
\hline Rarely & 7.3 & 8.3 & 一 & - \\
\hline At times of crisis & 4.6 & 5.3 & - & - \\
\hline$N=$ & 2511 & 469 & - & - \\
\hline
\end{tabular}

Source: World Values Study Group, World Values Survey 1990 (Ann Arbor: Institute for Social Research).

${ }^{a}$ Please say, for each of the following (religion), how important it is to your life? ${ }^{b}$ Independently of whether you go to the temple/church/mosque or not, would you say you are a religious person, not a religious person, a convinced atheist. ${ }^{c}$ To which of the following groups do you belong above all? ${ }^{d}$ Apart from weddings, funerals, and christenings, about how often do attend religious services these days? ${ }^{e} \mathrm{How}$ often do you pray to God outside of religious services?

state of Jammu and Kashmir. More recently, Vajpayee struck a conciliatory note with regard to relations with Pakistan and even rode the bus to Lahore to improve India-Pakistan relations, much to the displeasure of party hardliners. To them, it seemed like a compromise of the BJP's long-standing antipathy to Pakistan and its nationalist ideology. ${ }^{32}$ Furthermore, the political double-talk and 
often contradictory statements issued by the party leadership and the governmental leaders to keep both their supporters and opponents at bay helps to expose the unprincipled positions of BJP leaders. This point is illustrated by the tendency of BJP leader Pramod Mahajan, and sometimes Advani, to contradict Vajpayee until recently on issues related to foreign policy, Kashmir and, especially, the Babri Masjid issue. The fact that, despite these contradictions, the BJP-led alliance went on to win the 1999 elections is due to two factors. First, its policy of opportunistic alliances with regional parties helped to enhance it performance at the polls by extending its geographical reach. Second, and maybe more importantly, Vajpayee's own personal popularity had a lot to do with the victory. If one can go by the series of opinion polls conducted by different organizations and newspapers, support for Vajpayee far exceeded that for the BJP. This fact has helped to establish Vajpayee's predominant position within the party and vis-à-vis his allies. ${ }^{33}$

\section{Conclusion}

The Turkish experience suggests that an exclusionist policy of combating the perceived threat of nationalist-religious parties by forcing their closure or forcibly excluding them from power is anti-democratic and does not work. For, as the case of Turkey suggests, in democracies they tend to re-emerge under a different guise. In the Turkish case, even though the party was essentially operating according to the democratic rules of the game, and enjoyed widespread popular support, it was banned on the grounds that it violated the Kemalist dictum that a party must follow secular principles.

We have argued that a more appropriate strategy for dealing with nationalistreligious parties may be to include them in, rather than exclude them from the political system, as long as they are prepared to operate within the democratic framework. ${ }^{34}$ A policy of inclusion as part of a coalition exposes nationalistreligious parties to the political dynamics of a coalition government. As the leader of a coalition, they have to provide effective governance. That is easier said than done. At the same time, the party is deprived of the luxury of being able to sit on the sidelines and criticize an incumbent secular government. There is also the danger that efforts to bar these parties from gaining political power by force, as is the case in Algeria and Egypt, may lead to their greater radicalization and a shift towards violence and terrorism in order to attain their objectives. It also helps to negate the 'fairness' argument, so successfully exploited by the BJP after its first stint in government for 13 days.

The earlier spectacle of the 1998 coalition members of the BJP government like the All India Anna Diravida Munnetra Kazhagam (AIADMK) and Trinamool Congress (TMC) pulling the party in different directions might be indicative of what can be expected a year or two later in today's expanded coalition of over 20 parties. This political tug-of-war has confronted the BJP with the dilemna of trying to satisfy the demands of its coalition partners as well as its own constituents, especially the more radical wing. ${ }^{35}$ Also, allowing nationalist- 
religious parties to operate as part of a coalition government consisting of secular parties could help to contain any radical religious tendencies of the party.

The experiences of the RP in Turkey and the BJP in India suggest that efforts at coalition formation with secular parties forced them to compromise on their political and religious agenda. The re-making of the public image of the BJP in recent years is probably the most compelling testimony in support of a policy of inclusion. The resulting disillusionment among their hardcore supporters has resulted in intra-party conflicts between the moderates and the radicals. As Erbakan and Vajpayee learned the hard way, it is a dangerous proposition trying to ride the tiger of religious sectarianism and bigotry in order to gain and maintain power. Vajpayee's public declaration in 1998 that he would not again run for public office might have something to do with this realisation. The public criticism of the BJP's leadership as part of the earlier coalition, its willingness to compromise on its swadeshi plank, and its efforts to moderate its religious ideology could well form the basis of serious schisms within the party. Given the heavy dependence of the party on Prime Minister Vajpayee for its current popularity, his departure might result in the BJP being reduced to the position of a minor party should it try to reassert its Hinduvta ideology.

\section{Notes and references}

1. As suggested by Mark Jurgensmeyer, the use of the term 'fundamentalist' to describe religious-based parties tends to generate more heat than light. Besides having perjorative connotations, use of the term fails to distinguish between the fundamental division that exists within these parties in terms of a radical extremist wing and a usually more dominant moderate one. See Mark Jurgensmeyer, The New Cold War? Religious Nationalism Confronts the Secular State (Berkeley: University of California Press, 1996) pp 4-6.

2. Ashis Nandy, 'The politics of secularism and the recovery of religious tolerance', Alternatives, Vol 13, No 3, 1988. See also Ashis Nandy, 'An anti-secularist manifesto', Seminar, October 1985, pp 14-24; M. M. Thomas, 'Religious fundamentalism and Indian secularism: the present crisis', Journal of Dharma, Vol 19, No 1, January-March 1994, pp 26-35; and the articles on secularism and religious fundamentalis m in The Economic and Political Weekly Vol 28, No 28, 9 July 1994. For a non-mainstream view of the threat, see Yogendra K. Malik and Dhirendra K. Vajpayee, 'The rise of Hindu militancy: India's secular democracy at risk?', Asian Survey, Vol 29, No 3, March 1989 pp 308-325; Yogendra K. Malik and V. B. Singh, Hindu Nationalists in India: The Rise of the Bharatiya Janata Party (Boulder: Westview Press, 1994); and Eddie J. Girdner, 'Religion and politics: the case of India', Asian Thought and Society, Vol 21, Nos 61\&62, January-August 1996. Regarding the threat posed by the Refah Party to the secular Turkish state, see Binnaz Toprak, 'Islam and the secular state in Turkey', in Igdem Balin, Ersin Kalaycioglu, Cevat Karatas, Garret Winrow and Feroze Yasamee (eds), Turkey: Political Social, and Economic Challenges in the 1990s (New York: E. J. Brill, 1995), pp 89-96; E. Ozbudun, 'Islam and politics in modern Turkey: the case of the National Salvation Party', in B. F. Stowasser (ed), The Islamic Impulse (Washington DC: Kazi, 1987); Feroze Ahmed, 'Politics and Islam in modern Turkey', Journal of Middle Eastern Studies, Vol 27, No 1, January 1991, pp 11-21; Binnaz Toprak, Islam and Political Development in Turkey (Leiden: Brill Academic Books, 1981), pp 96-104; I. Sunar and B. Toprak, 'Islam in politics: the case of Turkey', Government and Opposition, Vol 18, No 4, 1983, pp 420-441; Mehmet Yasar Geyikdagi, Political Parties in Turkey: The Role of Islam (New York: Greenwood, 1984); and Jenny B. White, 'Pragmatists or ideologues? Turkey's welfare Party in power', Current History, January 1997, pp 25-30. In this paper we shall refer to the RP and the BJP as 'nationalist-religious' parties since a close reading of their policies and programs suggests a primarily nationalistic orientation rather than a religious one.

3. Adam Przeworski and Henry Teune, The Logic of Comparative Social Inquiry (New York: Wiley-Interscience, 1970).

4. See James Chiriyankandath, 'The politics of religious identity: a comparison of Hindu nationalism and Sudanese Islamism', Journal of Commonwealth and Comparative Politics, Vol 32, No 1, March 1994; and Ahmed, op cit, note 2 . 
5. Chiriyankandath, op cit, note 4, pp 32-33.

6. Ibid.

7. Sunil Adam, 'Bonfires of vanities and a catalogue of Ironies', India Abroad 13 March 1998.

8. The Turkish Daily News, press clippings, January 1997.

9. Sultan Halisdemir, 'The Islamist and the nationalists, The Turkish Daily News, November 1994, p B1; and Hayari Birlir, 'He who sows the seeds ...', The Turkish Daily News, April 1994, p A3.

10. Ahmed, op cit, note 2, pp 14-17; and Ahmad, The Turkish Experiment in Democracy 1950-1975 (London: Hurst, 1975) pp 363-388.

11. These businesses include the Islamic fashion industry along with book publishing, journals, magazines, newspapers, radio and even TV stations in recent years. See Sultan Halisdemir, 'Commercialization of Islam, or adding to the Islamic revival', Turkish Daily News, 11 February 1995, p B1.

12. Sultan, op cit, note 9. Also see Nilufer Narli, 'Islamic alliance in the city', Turkish Daily News, 7 April 1998 p B3.

13. For a comprehensive history of the Jan Sangh, see Craig Baxter, The Jana Sangh: A Biography of an Indian Political Party (Philadelphia: University of Pennsylvanni a Press, 1969), pp 6-80. On the BJP, see Christophe Joffe, Hindu Nationalism, 1925-1992 (London: C. Hurst, 1993).

14. Chiriyankandath, op cit, note 4 , pp 32-33.

15. Ibid.

16. World Values Study Group, World Values Survey 1990-1993 (Ann Arbor: Institute for Social Research). Data computed by authors. See also India Today-MARG opinion poll in India Today, 10 April 1996, p 53.

17. The scandal errupted with Rao initiating a Central Bureau of Investigation (CBI) investigation against some of his cabinet colleagues and prominent members of the opposition as to their involvement in hawala (illegal foreign exchange) transactions. The motivation behind this investigation, it was widely believed among political observers, was to undermine political opposition from within and outside the Congress(I). In early June, the CBI implicated Rao and a host of other leaders of having bribed four members of the Jharkand Mukti Morcha to get their support to undermine a no-confidence motion in Parliament against the Congress(I) government in 1993. In July, Rao was charged with accepting a $\$ 100,000$ bribe to secure a government contract. See Sumit Ganguly, 'India in 1996,' Asian Survey, Vol 37, No 2, February 1997, pp 127-128.

18. Survey of the International Republican Institute (Washington DC), as reported in Ugur Akinci, 'IRI survey: vote discontent peaks', 25 February 1995, p A2.

19. Turkish Daily News, 8 June 1996, p A5.

20. India Today, 31 May 1996, pp 22-27. See also N. K. Singh, 'Out but not down', India Today, 15 June 1996, p 37.

21. Hurriyet, 26 December 1995, p 19.

22. The Washington Post, 19 January 1998, p A19. See also The Turkish Daily News, 29 June 1996, p A1.

23. Javed M. Ansari, 'Gowda's gaffes ... and Kesri's curse', India Today, 30 April 1997, pp 14-16.

24. Ibid.

25. An India Today-MARG opinion poll conducted between 6 and 19 June reported that $56 \%$ of the public felt that the BJP was not a communal party, compared to $33 \%$ who thought it was. See India Today, 30 June 1966, p 30.

26. Times of India, 16 August 16, 1999 (internet edition).

27. Turkish Daily News, 21 March 1998, p B1.

28. Times of India, 23 June 1998. 'In coalitions compromises are a must', India Today, 2 November 1998. Saba Naqvi Bhaumik, 'Sangh vs Sanghi', India Today, 14 September 1998; Sumit Mitra and Harinder Baweja, 'RSS on the rampage', India Today, 28 September 1999, pp 12-17.

29. Calcutta Online, 23 June 1998. Internet news. Partho Chatterjee, 'How we loved the bomb and later rued it', The Economic and Political Weekly, Vol 33, No 24, 13 June 1998, pp 1437-1441.

30. World Values Survey, op cit, note 16.

31. On Erbakan's views, see Ahmed, op cit, note 2, pp 14-17, 382-383.

32. Harjinder Baweja and Zahid Hussein, 'Break Down', India Today, 19 August 1998, pp 30-34.

33. The series of opinion polls conducted prior to the elections illustrate this point. According to the Outlook and Center for Media Studies poll, 39\% expressed support for the BJP while 51\% chose Vajpayee to be the next Prime Minister of India. See Outlook, 15 August 1999, p 26. A Times of India, 14 August 1999, and India Today, 21 August, 1999 poll mirrored these results.

34. B. B. Lawrence, 'Muslim fundamentalist movements: reflections toward a new approach', in Stowasser, op cit, note 2 .

35. This point is well illustrated by the opposition of the Sangh Parivar to the visit of the Pope unless he was prepared to apologise for the allegedly forced conversion of Hindus to Christianity. 